\title{
Effect on Academic Achievement and Misconceptions of Pre-service Teachers through Combining Different Teaching Methods in a Preschool Science Course
}

\author{
Nur Akcanca ${ }^{1 *}$, Lale Cerrah Özsevgeç² \\ ${ }^{1}$ Early Childhood Education, Çanakkale Onsekiz Mart Üniversitesi, Turkey \\ ${ }^{2}$ Primary Education, Karadeniz Teknik Üniversitesi, Turkey \\ *Corresponding author: nurakcanca@,comu.edu.tr
}

\begin{abstract}
This study aimed to investigate the effects of different active teaching techniques on pre-school student teachers' concept learning and academic achievement. The study group consisted of 46 third year pre-school student teachers in a public university. Different active teaching methods were used during the single term Science Course, a compulsory course in the Preschool Programme. The treatment process took ten weeks in total (4 hours per week). The study had both qualitative and quantitative data. The quantitative data were collected using a three-tiered science concepts test, and qualitative data were collected through observation by the researcher. The alpha Cronbach values calculated for the test's reliability were 0.642 for Success-1 (S1) and 0.52 for Misconception-3 (MC3) scores. A dependent t-test was used to compare the pre and post-test scores of the pre-school student teachers. The researcher took observation notes during the in-class teaching exercises. The findings revealed that there were significant differences between the student teachers' pre and post-test scores. They understood science concepts significantly better by the end of the course. It is concluded that combining different teaching methods enhances science concept understanding among student teachers. In addition, misconceptions decreased after instruction.
\end{abstract}

Keywords Active teaching methods, Success, Conceptual understanding, Science education, Pre-school student teachers

\section{INTRODUCTION}

Preschool constitutes the first stage of the education system and uses a different education process from the other education stages. Preschool education program is planned by considering the characteristics of children's physical, mental, and emotional development. Pre-school education aims to prepare children for elementary education by developing their language, motor, and cognitive skills (Ministry of National Education [MoNE], 2013). At this stage, children are expected to develop their fine motor skills, express themselves well, and acquire selfcare skills. Furthermore, they are expected to recognize, categorize, and order the scientific phenomena occurring around them at a basic level. In this context, Turkish, science, mathematics, and art activities are used in education not as an aim but as a means for children's development in various aspects.

In the pre-school period, science is a part of children's games, investigations, inquiries, and experiences (Tahta \& İvrendi, 2010). Children at these ages are directly involved in relationships with living creatures and each other. Many scientific concepts include the sky, sun, moon, heat, temperature, sound, weight, environment, and environmental problems. Accordingly, many scientific concepts are constructed in minds during this life period (Demir \& Şahin, 2015). Meaningful construction of scientific concepts in the early stages is essential to facilitate future learning. While teaching new concepts, the teacher uses the students' previous knowledge. There are science activities in the Preschool Curriculum to teach some science concepts to children. It is crucial to teach these concepts correctly to ease the students' learning and teachers' teaching during elementary education (Gemici, 2008). In this context, it is essential that pre-school teachers, who will later be responsible for teaching these concepts, have also learned the science concepts correctly.

The related literature revealed that pre-school student teachers lacked competence in teaching scientific concepts (Brenneman, 2011). They had problems in knowledge

Received: 14 May 2020

Revised: 23 November 2020

Published: 28 November 2020 
levels regarding science concepts (Cho, Kim, \& Choi, 2003; Kallery, 2004). Çamlıbel Çakmak (2012) revealed that preservice pre-school teachers had misconceptions about the concepts related to heat and temperature, space, floating and sinking, and living things. Moreover, Timur (2012) determined that pre-school student teachers possessed many misconceptions about force and motion. Ültay \& Can (2015) concluded that pre-service pre-school teachers had knowledge problems related to heat and temperature. It is known that when pre-service teachers whom themselves possess this incorrect or inadequate information, or indeed these misconceptions, are appointed to their profession, there is a strong possibility that they will transfer these to their students (Çamlibel Çakmak, 2012). Based on the necessity to solve the problem at its source, it is crucial that candidates' conceptual understanding and knowledge levels are improved at the undergraduate level (Özbek, 2009).

In the pre-school teaching curriculum, there is a course named "Teaching Science in Early Childhood". This course expects candidates to learn science concepts and acquire skills to teach and plan science activities according to their children's ages and developmental levels (Alisinanoğlu, Özbey, \& Kahveci, 2011; Tahta \& İvrendi, 2010). Furthermore, pre-school teachers are required to comprehend the aim of science education in this course. They wanted to be equipped with teaching methods to make their children active and excited and make their learning meaningful (Demir \& Şahin, 2014). In studies conducted with pre-school teachers, it was determined that teachers experienced difficulties related to planning and implementing science activities and to use different techniques for teaching scientific concepts (Bilaloğlu, Aslan, \& Arnas, 2008). The methods such as an educational game, semantic network, drama, projects, brainstorming, problem-solving should be used to teach science (Sı̆̆ırtmaç \& Özbek, 2011). It is stated that teachers who cannot acquire skills at the desired level may be the root of their undergraduate education (Orçan, 2013). The study (Ayvac1, Devecioğlu, \& Yiğit, 2002) revealed that most pre-school teachers have limited knowledge about student-based teaching methods, and they prefer using traditional methods such as lecturing, questioning, and answering, demonstration and observation. It has been revealed that the science courses at the undergraduate level need revision in terms of their content as well as the methods and techniques used for the activities and experiments (Kallery, 2004; Bilaloğlu et al., 2008; Çamlıbel Çakmak, 2012). It is considered that a lesson procedure in which the active participation of pre-service teachers is enabled and science concepts are taught with applications can be helpful about increasing the quality of learning and reducing problems that may occur in the future (Okur Akçay, 2014; Demir \& Şahin, 2015). It is also believed that science instruction delivered within such a framework will eliminate existing misconceptions (Ültay \& Can, 2015).

In line with all this information, it was decided to combine some techniques which were stated as useful for science teaching education in the literature. So the main problem of this research consists of the question, "To what extent will a science instruction process, conducted by combining different active teaching methods that place the student at the center, be effective for pre-school student teachers' learning of science concepts?" Using more than one teaching technique serves different learning preferences of the other learners in the class. Thus it strengthens understanding more effectively. It is thought that the findings obtained in this study will make positive contributions to the planning of science courses at the undergraduate level and serve as a guide to faculty members teaching these courses.

This study aims to determine pre-school student teachers' learning and evaluate the effect of science education courses conducted with different teaching methods on success and conceptual understandings of preschool student teachers (PSTs).

\section{METHOD}

\subsection{Research Model}

In this study, one type of pre-experimental design, single-group pretest-posttest design, was used. During the study, one group is exposed to a treatment or condition, and then the results of the process are measured. A different control group was not used to evaluate this external intervention's effectiveness better, and a single group was worked. Since the aim was to examine in detail the student teachers' conceptual changes and achievement levels before and following the intervention, a single-group pre, and post-test practical research design model was used (Frankel \& Wallen, 2003).

\subsection{Research Group}

The sample of the study was in a state university located in Kars, Turkey. For the selection of the participants, a purposive sampling approach was used. Use of this sampling technique is preferred in exceptional cases that have specific criteria and characteristics (Büyüköztürk, Kılıç Çakmak, Akgün, Karadeniz, \& Demirel, 2014). In this study, 46 (35 females, 11 males) third-year pre-service students were selected for the study because they took a course titled "Science Education" and were learning science topics in this course. At the beginning of the study, a pre-test was taken from all student teachers, and then an experimental procedure was applied, which was prepared by the researchers. The same test was used as a post-test after the experimental procedure.

\subsection{Data Collection Tool}

To determine the student teachers' conceptual understanding levels and misconceptions related to the science concepts specified, a "Three-Tiered Science 
Table 1 Educational activities conducted with PSTs

\begin{tabular}{|c|c|c|}
\hline Themes/Subjects & & Activities \\
\hline \multirow{6}{*}{ 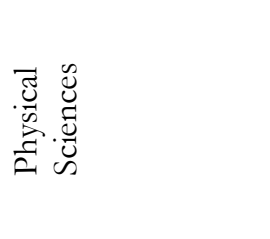 } & Theme: Matter & Popping balloons (Educational game) \\
\hline & Gravitational force & Who spokes the truth? (Concept cartoon) \\
\hline & Mass and Weight & Wet towel and popped balloon (Experiment) \\
\hline & & An apple fell from the sky (Story writing) \\
\hline & & What does a dynamometer look like? (Synthetic) \\
\hline & Theme: Space & The Magic School Bus in Space (Cartoon film) \\
\hline \multirow{5}{*}{ 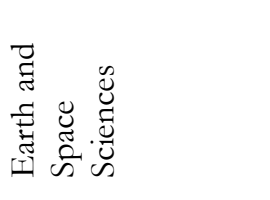 } & Solar System & Look at the first letters (Acrostic activity) \\
\hline & Planets & Examining materials in the solar system \\
\hline & & Spin around me (Creative drama) \\
\hline & & Space journey (Product design) \\
\hline & & What are they talking about-1? (Cartoon completion) \\
\hline \multirow{5}{*}{ 莺 } & Theme: Space & Giant-dwarf following activity (Educational game) \\
\hline & Movement of the Earth and & What happened to the sun? (Thought-provoking questions) \\
\hline & moon & Solar and lunar eclipses (Experiment) \\
\hline & High/Low Tides & Tidal festival in China (Creative drama) \\
\hline & Theme: Environment & Freeze! (Still image) \\
\hline \multirow{5}{*}{ 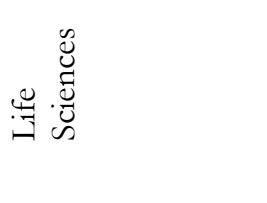 } & -Living Organisms & Categorization of living organisms (Presentation) \\
\hline & -Categories of Living Organisms & Let me categorize living organisms (Semantic network) \\
\hline & & What if it were like this? (Scamper) \\
\hline & & Let's combine ideas (Bread and butter technique) \\
\hline & Theme: Environment & Asya’s letter (Case Study-Creative problem solving) \\
\hline \multirow{5}{*}{ 兽 } & Greenhouse Effect & Let's form a committee (Six action shoes) \\
\hline & Global Warming & Let's read memos (Conceptual change text) \\
\hline & & Let's find keywords (Puzzle) \\
\hline & & Migrating birds (Story completion) \\
\hline & Theme: & Who am I? (Puzzles) \\
\hline \multirow{4}{*}{ 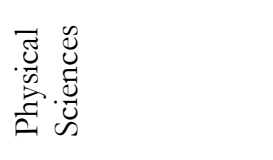 } & Matter & Ali's voice (Case Study-Creative problem solving) \\
\hline & Sound & What kind of tool is a telephone? (Ordering qualities) \\
\hline & & What are they talking about-2? (Cartoon completion) \\
\hline & & Can you hear me? (Roleplay) \\
\hline \multirow{11}{*}{ 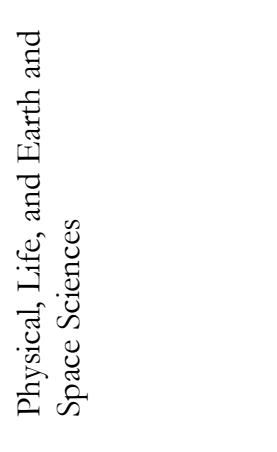 } & Theme: & Let’s learn while traveling (Station technique) \\
\hline & Matter & What are they talking about-3? (Cartoon completion) \\
\hline & Environment & Let's write a story (Familiar story adaptation) \\
\hline & Space & Let's sing (Song composition) \\
\hline & & Global warming! (Poster preparation) \\
\hline & & Environment friendly (Product development) \\
\hline & & Pitchfork, glass flute, and making a duck sound with vibrations \\
\hline & & (Experiment) \\
\hline & & Lifesaving lunar eclipse (Story completion) \\
\hline & & Design your own space (Product design) \\
\hline & & Grandpa doesn’t sleep (Experiment) \\
\hline 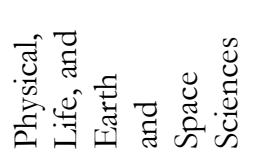 & $\begin{array}{l}\text { Theme: Matter-Environment- } \\
\text { Space }\end{array}$ & Let's make our own mental map (Mental map) \\
\hline
\end{tabular}

Concepts Test" (TTSCT) was developed. At the first tier of the test, there was a question searching student teachers' knowledge. In the second tier, the reasons for the answer given to the first question. In addition to the four reasons, an 'e' option was given to elicit the PSTs' misconceptions, and an adequate space was given for the question "What do you think the reason should be?". The third tier was the confidence tier to examine whether the PSTs were sure or not their previous answers.

Basic science concepts included in the Science Education course comprise three main science fields: life

DOI: $10.17509 / j$ sl.v4i1.24672 sciences, physical sciences, and earth and space sciences (Gonzalez et al., 2011; Martin, 2012). The questions included in the TTSCT were prepared for the subjects of (I) sound, mass, weight, and gravity for physical sciences, (ii) living organisms and their categories, global warming, and the greenhouse effect for life sciences, and (iii) solar system, movements of the Earth, sun, and moon for Earth and space sciences. While preparing the TTSCT, firstly, the concepts for the relevant science subjects were determined, and the misconceptions related to these concepts mentioned in the literature were examined. Some of the 
questions were obtained directly from the sources examined, while the lecturers prepared others.

Furthermore, the changes in the conceptual understanding levels of PSTs were determined based on the researcher's observation records during the in-class teaching practices. The observation data, which included video recordings, were systematically evaluated, arranged, and reported at each lesson's end.

\subsection{Teaching process}

The research's implementation stage was completed in 40 hours (4 hours per week). Lessons in which pre and post-test were implemented were excluded from this period. During the treatment process, which lasted for one term, several different techniques were used. Before the instruction, other active teaching techniques were planned based on the characteristics of the topics. These techniques are concept map, semantic network, brainstorming, case study, mental map, scamper, role play, creative drama, still image, story writing, synthetic, cartoon completion, six action shoes, station technique, creative problem solving, thought-provoking questions.

Some activities were planned as individual projects, whereas others were designed for team works to provide peer interactions. Members of the groups were determined according to classmates with whom they had less interaction. The first two weeks of instruction were carried out in pre-briefing and introduction to the teaching techniques. The activities used for subjects of the science education course were given in Table 1.

\subsection{Data Analysis}

For scoring the TTSCT, the responses that PSTs gave to each of the three tiers for each question were coded on an Excel sheet. The coding was made according to the scoring system created by Göksu (2011), and an example has been provided to explain how questions were scored.
PSTs questions in the first three tiers were recorded in three categories: correct, incorrect, or misconceptions. If a PST chose answer $\mathrm{c}$ for item 7, $\mathrm{c}$ for 7.1, and a for 7.2. All these three answers are correct, and the PST"s point was recorded as 1 in the correct row, and a score of 0 was recorded in both the incorrect and misconceptions rows. Coding questions calculate the Success-1 (S1) score as 1 point if students' teachers' answers to first-tier questions are correct. The Success-2 (S2) score is obtained by evaluating the students' responses to the items' first and second tiers. When a student-teacher selects the correct statement at the first tier and chooses the valid reason, his/her S2 score was coded as 1, while incorrect and misconception lines were coded as 0 . Finally, the Success3 (S3) score was calculated by taking all three stages into account, and coding was made as 1 point in case of certainty for the answer.

They were assuming that PST chose answer $\mathrm{d}$ for question 7, $\mathrm{d}$ for 7.1, and 7.2. Since a response of $\mathrm{d}$ indicates that the respondent has misconceptions regarding this question's content, a score of 1 was recorded in the misconceptions row. A response of $\mathrm{d}$ in Tier 2 supports the same misconception. A score of 1 was recorded in the misconceptions row. The respondent indicated that he was confident of the response he gave in Tier 1 by selecting a response in Tier 3. All these scores were taken into consideration when calculating the PST's Misconception-1 (MC1), Misconception-2 (MC2), and Misconception-3 (MC3) points. An independent t-test was performed for the scores obtained by the PSTs' pre, and post-test.

Observational data consisted of both in-class observational notes, and video recordings were analyzed together with personal documents. The data obtained from these documents were used to support or refute the data collected during observations or offer an alternative interpretation of the study's findings.

Table 2 Dependent t-test analysis of PSTs' pre and post-test Success-1, 2, and 3 scores on the TTSCT

\begin{tabular}{|c|c|c|c|c|c|c|c|}
\hline Class & Test & $\mathbf{N}$ & $\bar{X}$ & S & SD & t & $\mathrm{p}$ \\
\hline \multirow[t]{2}{*}{ TTSCT S1 } & Pre-test & 46 & 6.98 & 3.84 & 45 & 5.96 & $.000^{*}$ \\
\hline & Post-test & 46 & 10.20 & 2.17 & & & \\
\hline \multirow[t]{2}{*}{ TTSCT S2 } & Pre-test & 46 & 6.87 & 3.84 & 45 & 6.08 & $.000^{*}$ \\
\hline & Post-test & 46 & 10.17 & 2.24 & & & \\
\hline \multirow[t]{2}{*}{ TTSCT S3 } & Pre-test & 46 & 5,17 & 3,47 & 45 & 8.05 & $.000^{*}$ \\
\hline & Post-test & 46 & 8,89 & 2,47 & & & \\
\hline
\end{tabular}

${ }^{*} \mathrm{p}<.05$

Table 3 Dependent t-test analysis of PSTs' pre and post-test Misconception-1, 2, and 3 scores on the TTSCT

\begin{tabular}{llllllll}
\hline Class & Test & $\mathbf{N}$ & $\mathbf{\overline { X }}$ & $\mathbf{S}$ & $\mathbf{S D}$ & $\mathbf{t}$ & $\mathbf{p}$ \\
\cline { 2 - 4 } & Pre-test & 46 & 6.98 & 3.75 & 45 & 5.99 & $.000^{*}$ \\
& Post-test & 46 & 3.78 & 1.87 & & & \\
TTSCT MC2 & Pre-test & 46 & 6.89 & 3.79 & 45 & 5.81 & $.000^{*}$ \\
& Post-test & 46 & 3.74 & 1.93 & & & \\
TTSCT MC3 & Pre-test & 46 & 5.61 & 4.18 & 45 & 4.94 & $.000^{*}$ \\
& Post-test & 46 & 2.72 & 1.98 & & & \\
\hline
\end{tabular}

$*_{\mathrm{p}}<.05$ 


\subsection{Validity and Reliability of Data Collection Tools}

Content validity of the TTSCT was examined by calculating incorrect negative and incorrect positive numbers. A false negative case is selecting the wrong answer for the first tier of the question and choosing the second tier's right reason. An incorrect positive case is selecting correct answers and a false explanation of the reason (Hestenes \& Halloun, 1995). Furthermore, choosing the correct answer and the correct explanation of the reason is defined as scientific knowledge; however, giving an incorrect answer and a false explanation is defined as knowledge deficiency (Peşman, 2005; Göksu, 2011). The incorrect positive rate for the TTSCT was calculated as $6.52 \%(n=3)$, and the incorrect negative rate was calculated as $8.69 \%(\mathrm{n}=4)$.
In comparison, the incorrect positive and incorrect negative rates for the post-test were calculated as $4.35 \%$ $(\mathrm{n}=2)$. The fact that the false negative, incorrect positive, and knowledge deficiency percentages of the TTSCT were estimated to be below the limit value of $10 \%$ indicates that the test is reliable (Hesteness \& Halloun, 1995). The Cronbach's alpha values calculated for the reliability of the TTSCT were 0.642 for $\mathrm{S} 1$ scores and 0.52 for M3 scores. Moreover, item-total correlations were examined, questions with negative correlations were removed from the test, and 15 items were obtained. The questions of the test were viewed by two academicians, experts in science education.

For the test's structure validity, the correlation between the correct answers of the first two tiers, and the case of

Table 4 Misconceptions of PSTs based on their pre and post-test Misconception-3 scores about the concept of matter

\begin{tabular}{lll}
\hline Misconceptions & Pre & Post \\
\hline Matter & & \\
\hline M1. Mass is the name given to the weight of matter. & $17 \%$ & $9 \%$ \\
M22. Weight is the name given to an object's mass. & $17 \%$ & $9 \%$ \\
M3. An object's mass decreases on the moon in comparison to its mass on the Earth. & $28 \%$ & $20 \%$ \\
M4. Weight is measured using balance scales. & $74 \%$ & $52 \%$ \\
S1. We hear thunder after lightning strikes as a result of the sound's reverberating. & $24 \%$ & $9 \%$ \\
S2. We cause the sound to be thinner when we decrease a radio's sound volume. & $4 \%$ & $0 \%$ \\
S3. A portion of the sound is lost when sound volume is decreased. & $39 \%$ & $4 \%$ \\
\hline
\end{tabular}

Table 5 Misconceptions of PSTs based on their pre and post-test Misconception-3 scores about the concept of environment

\section{Environment}

G1. Global warming causes the ozone layer to decrease in thickness.

G2. Global warming means that the Earth's temperature is the same in every part of the world.

G3. Reducing CO2 amounts will not impact global warming.

L1. Whales are members of the fish family.

L2. Seals are members of the fish family.

L3. Plants feed on their roots.

L4. Plants obtain their substance by breathing.

L5. Penguins are mammals.

L6. Penguins are members of the frog family.

L7. Penguins are members of the fish family.

$\begin{array}{ll}33 \% & 24 \% \\ 0 \% & 2 \%\end{array}$

$26 \% \quad 4 \%$

$24 \% \quad 13 \%$

$17 \% \quad 4 \%$

$67 \% \quad 57 \%$

$7 \% \quad 4 \%$

$22 \% \quad 9 \%$

$2 \% \quad 2 \%$

$13 \% \quad 4 \%$

Table 6 Misconceptions of PSTs based on their pre and post-test Misconception-3 scores about the concept of space Space

SP1. The moon is the largest object in space.

SP2. The Earth is larger than the sun and the moon.

$\begin{array}{ll}13 \% & 2 \% \\ 24 \% & 2 \% \\ 0 \% & 2 \% \\ 41 \% & 24 \% \\ 13 \% & 0 \% \\ 13 \% & 11 \% \\ 24 \% & 15 \% \\ 17 \% & 0 \% \\ 30 \% & 9 \%\end{array}$

SP3. The Milky Way Galaxy is bound to the sun.

SP4. Jupiter is a large star.

SP5. There is air in space.

SP6. The moon's size changes depending on its phase.

SP7. The moon does not revolve around the sun.

SP8. The moon does not revolve around itself.

SP9. Earth is the largest planet. 
7. In the following question, which given class is correct for the penguin?

a. penguin-Amphibia

b. penguin-Mammals

c. penguin-Birds

d. penguin-Fishes

7.1. Which one of the followings is the reason of your answer for the previous question?

a. penguins are capable of living both on land and in water, hence they are in the amphibian group.

b. penguins give birth to their young ones, hence they are in the mammal class.

c. the body of the penguins are covered with feathers, hence they are birds.

d. wings of the penguins serve as a fin, therefore they are birds.

e. None of them (what is your explanation?)

7.2. Are you sure about your answers for the previous question?

a. I am sure

b. I am not sure

Figure 1 Example question from the T'TSCT

certainty for the third tier (reliability level) was examined. The correlation coefficient was calculated as 0.222 for S2, at a 0.01 significance level. When the PSTs' scores increased at the second tier, an increase in reliability levels was also observed. It means that the student teachers gave correct answers, and they were also sure of their responses. A low relationship between the misconceptions and reliability level means that student teachers had misconceptions, and they were not entirely sure of their answers.

Furthermore, the observation notes, which were another measurement tool, were supported with the statements obtained in the data collected from the written documents. While these statements were being made, codings in PST1, PST13, and PST16 were used.

\section{RESULT}

Table 2 represents the dependent t-test for the differences between PSTs' pre and post-test Success-1, 2, and 3 scores. In Table 2, significant differences were found between pre-and post-test scores at all three stages of the three-tier test (Success-1, 2, and 3). It was revealed that all scores related to success were increased after treatment. It was also determined that the rate of correct answers given to the question in the first stage of the three-tier test was higher than the appropriate steps regarding the explanation of the answer and whether or not to be sure about the answer. Although tiers scores increased, average pre-and post-test success scores decreased. It is thought that the practices carried out throughout the research process

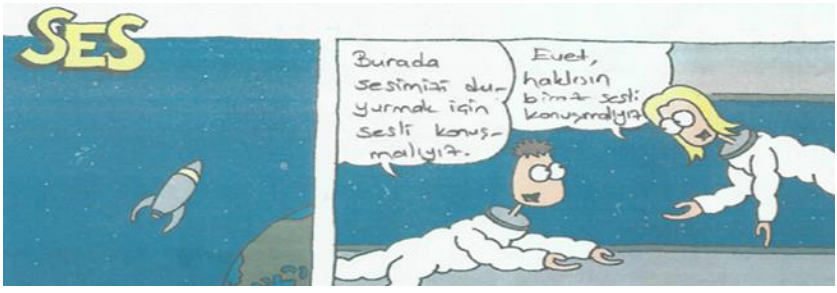

Figure 2 An example from cartoon completion activity (Özdemir, 2006; pp. 19) positively affect the success of pre-service teachers in related science subjects.

In Table 3, when the pre-service teachers' misconception scores obtained from all three stages of the test are examined (Misconceptions-1, 2, and 3 scores), significant differences were found between pre and posttest scores. Average misconception scores decreased for all three-tier of the test after the experimental process. It is thought that the practices carried out throughout the research process are useful in overcoming the pre-service teachers' misconceptions in related science subjects.

In the following tables, misconceptions were presented coding as Mass (M), Sound (S), living organisms (L), Global Warming (G), Space (SP). Although some misconceptions (M3, M4, G1, L3, SP5, SP8) were decreased in the posttest, some misconceptions were resistant to change and not eliminated. This finding obtained from the research will be explained with the observation data in the next title.

As seen in Table 4, although the ratios of the misconceptions of PST decreased in the post-test, the misunderstanding about the matter was still higher. The effectiveness of the synectic technique is also tricky for application in the class because of this result.

Pre: PSTs' misconceptions on the pre-test Post: PSTs' misconceptions on the post-test. As shown in Table 5, the percentages of the misconceptions were low in the posttest, but the statement's ratio as "Plants obtain their substance from the soil via their roots" was still high. This belief is quite common among the students from primary school to university, so it may be resistant to change. Their thoughts may back to old after the instruction. As presented in Table 6 , the ratios of the misconceptions about space were low in the post-test.

\subsection{Observational Results About the Teaching Process}

PSTs' misconceptions were observed during class activities. During concept cartoon activities, PSTs were observed to confuse mass and weight concepts and had problems with measurement units. They believed that an object's mass on Earth and the moon was the same but had trouble describing weight. Some PSTs stated that an object's weight in space either changed as it did on the moon or decreased. A few PSTs said, "Weight was zero in space because there was no gravity in space." PST6 stated that "I do not think that matter's mass or weight changes. However, there may be gravity, but they still do not change." After the cartoon activity concept, PST6 changed his idea as "weight was matter's unchanging identity that does not change on the Earth or the moon". PST44 stated that "Weight changes depending on gravity. It can be different in various places of the Earth, and the source of gravity is the core. Weight is less at the equator and more at the poles. An object's mass does not change; it never changes anywhere" after the activity. PSTs wrote stories regarding mass and weight from the perspective of a tree or an apple. It is a fact that understanding mass, sound, 


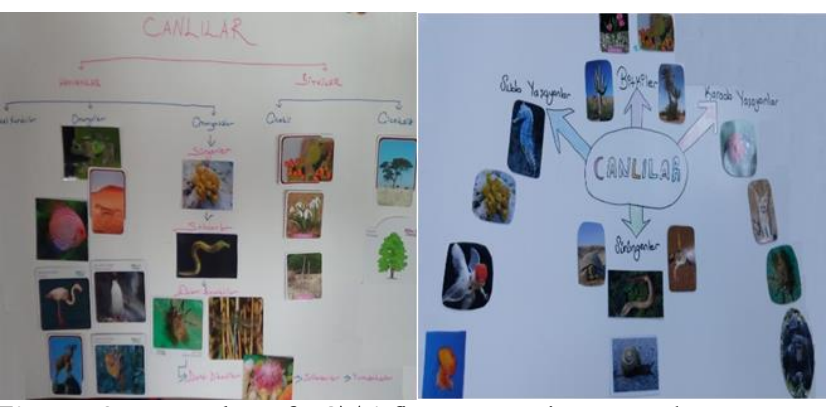

Figure 3 Examples of PSTs' first semantic networks

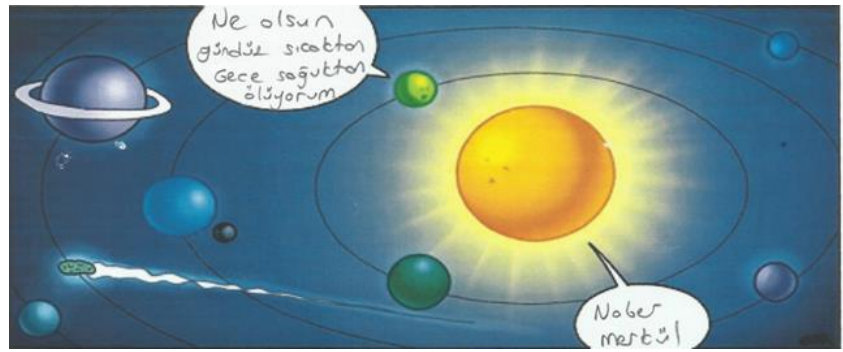

Figure 4 Cartoon completion by PST39

global warming, and living organisms poses challenges for students at different educational levels. Because of reasons such as complexity of the concept, teaching method, and textbook, students memorize the science concepts without deeper understanding at the primary level. This limited understanding of students causes negative feelings to science learning, and students carry these learning problems to the next school level.

PSTs were also observed to confuse reverberation and speed of sound. One group designed creative drama for teaching the statement that "thunder is heard after lighting is seen". Figure 2 shows an example from the cartoon completion activities of groups. It revealed their beliefs that sound could be transmitted in space and that the characters needed to speak louder.

For eliciting misconceptions of PSTs about living organisms, semantic network activity was planned. They were given pictures of living organisms to prepare their semantic networks. Before the activity, they were observed that they had learning problems of classification of living organisms. Figure 3 shows examples of semantic networks prepared by two PSTs before the application. The figure divided living organisms into plants and animals or organisms that live in water, organisms that live on land, and reptiles.

Figure 3 reveals that although they still exhibited incorrect understandings, PSTs could categorize living organisms much more accurately than previously. PSTs also mentioned microscopic organisms and mushrooms and gave correct examples of flowering and non-flowering plants and vertebrates and invertebrates.

PSTs were observed to have problems conceptualizing the solar system, the essential characteristics of planets, the sun, Earth, and moon's size and the relationship between space and the atmosphere under the theme space. PSTs were shown a cartoon film about planets. Following the film, faulty parts of the film were asked and discussed. PSTs were also asked to write an acrostic poem. One PST's acrostic poem for Venus, for example, highlighted that it was known as the Earth's twin and mentioned that it was the hottest of all planets. They also completed the cartoons. Figure 4 represents an example of the cartoons that PSTs completed. The study's main conclusions may be presented in a short Conclusions section, which may stand alone or form a subsection of a Discussion or Results and Discussion section.

Figure 4 reveals that PST39 was aware that Mercury was the closest planet to the sun and that both day and night on this planet were scorching. In other cartoons, PSTs were found to have learned that Venus had dense clouds of sulfuric acid, that Jupiter could be seen with the naked eye, and that the surface of Mars was red because of iron oxide. PSTs also learned the correct order of planets by size.

The observation records showed that PSTs were made aware of their misconceptions and adopted correct thinking frames by using various active teaching techniques. After the treatment process, it was observed that PSTs had fewer misunderstandings and to be able to adapt newly acquired scientific information to new situations they encountered.

\section{DISCUSSION}

The aim of using different active teaching methods is to affect academic achievement and conceptual understanding of pre-school. Post-tests' scores revealed that PSTs' success scores increased for all three tiers after the treatment process. Various teaching techniques and approaches (Ayverdi, Asker, Öz Aydın, \& Sarıtaş, 2012; Buntod, Suksringam, \& Singseevo, 2010) were found to have a positive impact on students' academic performance. These findings from other studies are consistent with the findings of this study. The PSTs' post-test average misconception scores also showed that their misconception scores decreased for all three tiers after the experimental process. The test results also revealed that PSTs were continuing to have some misconceptions such as mass and weight, but their ratios were lower than the beginnings. This result supports the idea that some misconceptions are persistent to change. The result of this research agrees with Koray, Özdemir, and Tatar (2005). The concept cartoons that PSTs completed in this study were thought to reduce their mass and weight misconceptions.

In contrast, educational games, story writing, and synthetic techniques were not sufficiently significant to overcome PSTs' misconceptions. Yağbasan and Gülçiçek (2003) stated that misunderstandings are not structured differently from students' other knowledge, and they are included in newly acquired information. Therefore, they mentioned the difficulty of eliminating misconceptions. 
Considering that pre-service teachers develop their misconceptions due to their own experiences and observations over a long time, it is an expected result that some misconceptions will not be eliminated. In this study, the related gains' time may not have been sufficient to eliminate the pre-service teachers' misconceptions.

PSTs had misconceptions regarding sound before the implementation. Many other researchers also determined similar misconceptions of the students from different educational grade levels (Hrepic, 2002; Küçüközer, 2009). The post-related gains' times of the PSTs decreased. Using concept cartoons, creative problem solving, and role play may help overcome the PSTs' misconceptions. In the literature, studies are supporting this idea (Atasoy, Tekbıyı, \& Gülay, 2013; Çalık, Okur, \& Taylor, 2011).

PSTs also had learning problems about the classification of living organisms. Türkmen, Çardak, \& Dikmenli (2005) found that students had incorrect knowledge about the diversity and classification of living organisms and semantic networks were highly effective in eliminating these misconceptions. Kaya (2010) concluded that conceptual change texts effectively reduced university students' misconceptions about photosynthesis and respiration. Techniques like scampers and semantic networks were effective in diminishing misconceptions of PSTs in this study.

PSTs also had incorrect knowledge about global warming and the greenhouse effect like other students at different grade levels (Bal, 2004; Ünlü, Sever, \& Akpınar, 2011). It was observed that they had even corrected several of these misconceptions after usage of techniques as cooperative learning, conceptual change texts, creative problem solving, and six action shoes.

Data collected on the theme of space revealed that PSTs had several misconceptions about the solar system, planets, sun, Earth, and moon, and the relationship between space and the atmosphere. Specifically, different grade levels of students were found to have gaps in their knowledge of astronomical concepts (Caballero, Moreira, \& Rodriguez, 2008; Tasscan \& Ünal, 2016). The present study found that the PSTs' insufficient knowledge was partially filled using animation and cartoon films and drama during the treatment process. Demirel and Aslan (2014) found that concept cartoons effectively eliminated students' misconceptions about the solar system held by students. Türk, Alemdar, and Kalkan (2012) found that students' participation in hands-on learning activities was beneficial for meaningful learning of astronomy subjects. Conduction of relation between science content and daily life events was also useful for students' meaningful learning. On the other hand, it was observed that experiment-based activities and product design techniques were not significant enough to overcome the misconceptions of the PSTs.

\section{CONCLUSION}

In summary, this study's activities facilitated PSTs' learning by giving them the responsibility for their education. They also enjoyed the learning process, and this increased their learning motivation. Thus, meaningful learning may have been achieved. The findings of the research of Bulunuz (2012) also support these studies' results. Group working may help get away PSTs' boringness in the classroom and reduce their learning stress. Representing active teaching techniques and a democratic instructional atmosphere, cooperative learning may help facilitate instruction and elicit misconceptions. Shortly, PSTs constructed their meaning by discussing, watching, listening, writing, reading, and making.

Based on all conclusions, it may be suggested that: preschool student teachers had problems learning science concepts, and they had misconceptions about science concepts. The lecturer should be aware of these misconceptions. S/he should be planned lessons by using different active teaching methods. Both group and individual activities should be used. A democratic learning environment should be created. It is remembered that misconceptions may be persistent to change. When designing similar studies in the future, it is recommended to determine these persistent misconceptions and develop a treatment process based on these conceptions with different activities.

\section{ACKNOWLEDGMENT}

The authors would like to acknowledge and thank the student teachers for their participation in the research.

\section{REFERENCES}

Alisinanoğlu, F., Özbey, S., \& Kahveci, G. (2011). Erken çocukluke döneminde fen eğitimi [Science education in early childhood]. Maya Academy.

Atasoy, Ş., Tekbiyık, A., \& Gülay, A. (2013). The effect of concept cartoons on understanding of sound concept of fifth grade students. Journal of Turkish Science Education, 10(1), 176-196.

Ayvac1, H. Ş., Devecioğlu, Y., \& Yiğit, N. (2002). Okulöncesi ögretmenlerinin fen ve doğa etkinliklerindeki yeterliliklerinin belirlenmesi [Determining efficacy of preschool teachers in science activities]. Paper presented at the National Science and Mathematics Congress, Ankara.

Ayverdi, K., Asker, E., Öz Aydın, S., \& Sarıtaş, T. (2012). Determination of the relationship between elementary students' scientific creativity and academic achievement in science and technology courses. Elementary Education Online, 11(3), 646-659.

Bal, Ş. (2004). Determining misconceptions about science teacher candidates about greenhouse effect. Eurasian Journal of Educational Research, 17, 102-111.

Bilaloğlu, R. G., Aslan, D., \& Arnas, Y. A. (2008). The analyzing of preschool teachers' levels of knowledge about science activities. National Educational Journal, 178, 88-104.

Brenneman, K. (2011). Assessment for pre-school science learning and learning environments. Early Childhood Research \& Practice, 13(1), 19.

Bulunuz, M. (2012). Developing Turkish pre-service pre-school teachers' attitudes and understanding about teaching science through play. International Journal of Environmental \& Science Education, $7(2), 141-166$ 
Buntod, C. P., Suksringam, P., \& Singseevo, A. (2010). Effects of learning environmental education on science process skills and critical thinking of mathayomsuksa 3 students with different learning achievements. Journal of Social Sciences, 6(1), 60-63. http://doi:10.3844/jssp.2010.60.63

Büyüköztürk, Ş., Kılıç Çakmak, E., Akgün, Ö. E., Karadeniz, Ş., \& Demirel, F. (2014). Bilimsel arastrrma yöntemi (16. bask1) [Scientific research method (16 th edition)]. Ankara: Pegem Academy.

Caballero, C., Moreira, M. A., \& Rodriguez, B. L. (2008). Concept mapping as a strategy to explore teachers' mental representations about the universe, concept mapping: Connecting educators. In Proceedings of 3th International Conference on Concept Mapping, Finland. Tallinn, Estonia and Helsinki.

Cho, H. S., Kim, J., \& Choi, D. H (2003). Early childhood teachers' attitudes toward science teaching: A scale validation study. Educational Research Quarterly, 27(2), 33-42.

Çalık, M, Okur, M., \& Taylor, N. (2011). A comparison of different conceptual change pedagogies employed within the topic of "sound propagation". Journal of Science Education and Technology, 20, 729-742. http://doi:10.1007/s10956-010-9266-z

Çamlıbel Çakmak, Ö. (2012). Examining the relationship between preschool teacher candidates' attitudes towards science education and understanding levels of science concepts. Journal of Turkish Science Education, 9(3), 40-51.

Demir, S., \& Şahin, F. (2015). Pre-school teacher candidates' beliefs about to make experiments by using $5 \mathrm{e}$ method. The Journal of Academic Social Science Studies, 35, 385-397. http://dx.doi.org/10.9761/JASSS2808

Demir, S., \& Şahin, F. (2014). Assessment of open-ended questions directed to prospective science teachers in terms of scientific creativity. Procedia-Social and Behavioral Sciences, 152, 692-697. https://doi.org/10.1016/j.sbspro.2014.09.264

Demirel, R., \& Aslan, O. (2014). The effect of science and technology teaching promoted with concept cartoons on students' academic achievement and conceptual understanding. Journal of Theory and Practice in Education, 10(2), 368-392.

Frankel, J. R., \& Wallen N. E. (2003). How to design and evaluate research in education. McGraw Hill.

Gemici, Ö. (2008). Fen ve teknoloji eğitiminde kavram ögretimi [Concept teaching in science and technology education]. In Ö. Taşkın (Ed.). Fen ve Teknoloji Ögrretiminde Yeni Yaklasımlar [New Approaches in Science and Technology Teaching] (pp. 125-148). Pegem Academy.

Gonzalez, J. E., Pollard-Durodola, S., Simmons, D. C., Taylor, A. B., Davis, M. J., Kim, M., \& Simmons, L. (2010). Developing lowincome preschoolers' social studies and science vocabulary knowledge through content-focused shared book reading. Journal of Research on Educational Effectiveness, 4(1), 25-52.

Göksu, V. (2011). Sorgulamaya dayal ve doğrulama laboratuvar ögretiminin fen bilgisi ögretmen adaylarmm basarlar, kuvvet ve bareket hake.endaki kavram yamlgzlar ve epistemolojik inanclar üzerindeki etkisi [The effects of inquiry based and verification laboratory instruction on preservice science teachers' achievement, misconceptions about force and motion and their epistemological beliefs] (Unpublished doctoral thesis). Gazi University, Ankara.

Hestenes, D., \& Halloun, I. (1995). Interpreting the force concept inventory. The Physics Teacher, 33, 502-506. https://doi.org/10.1119/1.2344278

Hrepic, Z. (2002). Identifying students' mental models of sound propagation (Unpublished master's thesis). Kansas State University, Manhattan.

Kallery, M. (2004). Early years teachers' late concerns and perceived needs in science: An exploratory Study. European Journal of Teacher Education, 27(2), 147-165 https://doi.org/10.1080/026197604200023024

Kaya, F. (2010). Fen bilgisi ögretmen adaylarmm bitkilerde fotosentez ve solunum konusundaki yanlgilarmm üstesinden gelmek için bilgisayar destekli kavramsal değissim metin talimatlarmm etkisi [The effects of computer assisted conceptual change texts instructions on overcoming preservice science teachers' misconceptions of photosynthesis and respiration in plants] (Unpublished master's thesis). Pamukkale University, Denizli.

Koray, Ö., Özdemir, M., \& Tatar, N. (2014). Primary school student's misconceptions about "units": Example of mass and weight. Primary Education Online, 4(2), 24-31.

Küçüközer, A. (2009). Investigating prospective science teachers' misconceptions of sound. Primary Education Online, 8(2), 313-321.

Martin, D. J. (2012). Elementary science methods: A constructivist approach (6 $6^{\text {th }}$ edition). Wadsworth.

Ministry of National Education [MoNE] (2013). Pre-school educational programme. General Directorate of Basic Education.

Okur Akçay, N. (2014). Determining the views and adequacy of the preschool teachers related to science activities. The Journal of Academic Social Science Studies, 30(1), 325-336. https://doi.org/10.13189/ujer.2016.040419

Orçan, A. (2013). Cizgi roman tekniği ile geliștirilen bilim kurgu bikayelerinin ögrencilerin yaratic düsünme becerileri ve fizile, tutumlarna etkisi [The effect of science-fiction stories developed by comics technique, on creative thinking skills and physics attitudes of students] (Unpublished master's thesis). Gazi University, Ankara.

Özbek, S. (2009). The analyze of pre-school teachers' sights of science education and its application (Unpublished master's thesis). Çukurova University, Adana.

Peşman, H. (2005). Development of a three-tier to assess ninth grade students' misconceptions about simple electric circuits (Unpublished master's thesis). Middle East Technical University, Ankara.

Sığırtmaç, A., \& Özbek, S. (2011). The analyze of pre-school teachers' opinions of science education and its implementation. E-Journal of New World Sciences Academy Education Sciences, 6(1), 1039-1056.

Tahta, F., \& İvrendi, A. (2010). Okul öncesi eğitimde fen ögrrenimi ve ögretimi (2. bask1) [Science learning and teaching in preschool education $\left(2^{\text {nd }}\right.$ edition)]. Kök Publishing.

Taşcan, M., \& Ünal, İ. (2016). An investigation of science teachers' knowledge levels of basic astronomy contents in terms of demographic variable. Necatibey Faculty of Education, Electronic Journal of Science and Mathematics Education, 10(1), 60-84. https://doi.org/10.17522/nefefmed.10897

Timur, S. (2012). Examining cognitive structures of prospective preschool teachers concerning the subject "force and motion". Educational Sciences: Theory and Practice, 12(4), 3039-3049.

Türk, C., Alemdar, M., \& Kalkan, H. (2012). Primary school students' seasons determination of understanding levels. Journal of educational and instructional studies in the world, 2(1), 62-67.

Türkmen, L., Çardak, O., \& Dikmenli, M. (2005). Using concept maps changing the misconceptions of the first-year high school students in biology courses in classification of living things and their diversity. Gazi University Journal of Gazi Educational Faculty, 25(1), 155-168.

Ünlü, İ., Sever, R., \& Akpınar, E. (2011). Analysis of the academic studies' results in environmental education in Turkey about global warming and greenhouse effect. Erzincan University Journal of Education Faculty, 13(1), 39-54.

Ültay, E., \& Can, M. (2015). Determination of pre-school student teachers' conceptual knowledge about heat and temperature. Karadeniz Journal of Social Sciences, 7(2), 1-23.

Yağbasan R., \& Gülçiçek Ç. (2003). Describing the characteristics of misconceptions in science teaching. Pamukkale University Journal of Education, 13, 110-128. 